\title{
The chronic effects of muscle-resistance training in arterial pressure of hypertensive older adults: a meta-analysis
}

\author{
Os efeitos crônicos do treinamento de resistência muscular \\ na pressão arterial de idosos hipertensos: uma metanálise
}

\section{Los efectos crónicos del entrenamiento de resistencia muscular en la presión arterial de los ancianos hipertensos: una metanálisis}

\author{
Priscila dos Santos Bunn $『[a, b]^{*}$, Nádia de Souza Lima $®[a]$, \\ Gabriela Rezende de Oliveira Venturini ${ }^{[a]}$, Elirez Bezerra da Silva ${ }^{[}{ }^{[a]}$
}

[a] Programa de Pós-Graduação em Ciências do Exercício e do Esporte, Universidade do Estado do Rio de Janeiro (UERJ), Rio de Janeiro, RJ, Brazil

[b] Centro de Educação Física Almirante Adalberto Nunes, Marinha do Brasil (CEFAN), Rio de Janeiro, RJ, Brazil

\begin{abstract}
Introduction: Little research has been done on the effects of muscle-resistance training (RT) in hypertensive older adults. Objective: The aim of this meta-analysis was to verify the efficacy of RT, on a chronic basis, on the systolic (SBP) and diastolic blood pressure (DBP) of hypertensive older adults. Method: Several literature databases were explored to find studies on controlled and randomized trials that evaluated the effects of RT in hypertensive older adults for more than 10 weeks. Profile of the participants, sample size, intervention protocol, and results of SBP and DBP were analyzed. The PEDro scale and the Cochrane tool were used to analyze the methodological quality of the studies and the risk of bias, respectively. The RevMan5.3 program was used
\end{abstract}

* PSB: Doctoral student, e-mail: priscilabunn@yahoo.com.br NSL: Doctoral student, e-mail: nadiaslimas@gmail.com GROV: Doctoral student, e-mail: gabriela-venturini@hotmail.com EBS: Doctoral student, e-mail: elirezsilva@cosmevelho.com.br 
to analyze the results on the SBP and DBP after the RT intervention and in the control groups. Results: The meta-analysis of five studies considering 96 hypertensive individuals who underwent RT and 104 hypertensive control subjects showed that the regular practice of RT from 12 to 16 weeks, three times a week, with three sets from 8 to 12 repetitions at an intensity of $60 \%$ to $80 \%$ of one-repetition maximum (1-RM), significantly reduced SBP by $7.26 \mathrm{mmHg}(95 \% \mathrm{CI}=-9.16-5.37)$ and DBP by $4.84 \mathrm{mmHg}(95 \% \mathrm{CI}=-5.89-3.79)$. Conclusion: The muscle-resistance training was effective in reducing, chronically, the blood pressure of hypertensive older adults. It can also decrease the need for medication inherent to hypertension.

Keywords: Resistance Training. Elderly. Hypertension.

\section{Resumo}

Introdução: Pouca pesquisa foi realizada sobre os efeitos do treinamento de resistência muscular (TR) em adultos idosos hipertensos. Objetivo: O objetivo da presente metanálise foi verificar a eficácia da TR, de forma crônica, na pressão arterial sistólica (PAS) e diastólica (PAD) de idosos com hipertensão controlada. Método: Várias bases de dados da literatura foram exploradas para encontrar estudos que examinaram ensaios clínicos controlados e randomizados que avaliaram os efeitos do TR em idosos hipertensos por um período de mais de 10 semanas. Foi analisado o perfil dos participantes, o tamanho da amostra, o protocolo de intervenção e os resultados da PAS e PAD. A Escala PEDro e a ferramenta Cochrane foram utilizadas para analisar a qualidade metodológica dos estudos e o risco de viés, respectivamente. O programa RevMan5.3 foi usado para analisar os resultados na PAS e PAD após a intervenção TR e nos grupos de controle. Resultados: A metanálise de cinco estudos incluiu que, considerando os 96 indivíduos hipertensos submetidos à TR e 104 sujeitos de controle hipertensos, a prática regular de TR por 12 a 16 semanas, três vezes por semana, com três séries de 8 a 12 repetições em uma intensidade de 60\% a 80\% do teste de uma repetição máxima (1-RM), reduziram significativamente a PAS em 7,26 $\mathrm{mmHg}$ (IC $95 \%=-9,16-5,37)$ e PAD por 4,84 mmHg (IC 95\% = -5,89 - 3,79). Conclusão: 0 treinamento resistido muscular foi eficaz na redução crônica da pressão arterial de idosos hipertensos controlados, podendo diminuir a necessidade de medicação anti-hipertensiva. Estes resultados implicam uma maior sobrevivência para esta população, bem como uma possivel diminuição da necessidade de medicamentos inerentes à hipertensão.

Palavras-chave: Treinamento de Resistência. Idosos. Hipertensão.

\section{Resumen}

Introducción: Poca investigación se realizó sobre los efectos del entrenamiento de resistencia muscular (ER) en adultos mayores hipertensos. Objectivo: El objetivo del presente metanálisis fue verificar la eficacia del ET, de forma crónica, en la presión arterial sistólica (PAS) y diastólica (PAD) de ancianos con hipertensión controlada. Método: Varias bases de datos de la literatura se exploraron para encontrar estudios que examinaron ensayos clínicos controlados y aleatorizados que evaluaron los efectos del ER en ancianos hipertensos por un período de más de 10 semanas. Se analizó el perfil de los participantes, el tamaño de la muestra, el protocolo de intervención y los resultados de la PAS y PAD. La Escala PEDro y la herramienta Cochrane se utilizaron para analizar la calidad metodológica de los estudios y el riesgo de sesgos, respectivamente. El programa RevMan5.3 fue utilizado para analizar los resultados en la PAS y PAD después de la intervención ER y en los grupos de control. Resultados: El metanálisis de cinco estudios incluyó que, considerando los 96 individuos hipertensos sometidos a ETy 104 sujetos de control hipertensos, la práctica regular de ET por 12 a 16 semanas, tres veces por semana, con tres series de 8 a 12 repeticiones en una intensidad del 60\% al 80\% de una repetición máxima (1-RM), redujo significativamente la PAS en 7,26 mmHg (IC 95\% = -9,16 - 5,37) y DBP por 4,84 mmHg (IC 95\% = -5,89 - 3,79). Conclusión: El entrenamiento resistido muscular fue eficaz en la reducción de la presión arterial de ancianos hipertensos controlados, crónicamente, y puede disminuir la necesidad de medicación antihipertensiva.

Palabras clave: Resistencia de Entrenamiento. Edad. Hipertensión. 
Introduction

Systemic Hypertension ( $\mathrm{SH}$ ) is the elevation of blood pressure levels above values considered normal for a certain age group, which is defined for young adults as systolic blood pressure (SBP) $\geq 140 \mathrm{mmHg}$, or diastolic blood pressure (DBP) $\geq 90 \mathrm{mmHg}$ [1], while for individuals aged 60 years or older, values of $\geq 150 / 90 \mathrm{mmHg}$ are considered [2].

$\mathrm{SH}$ is among the cardiovascular diseases whose prevalence has been increasing with age [3]. It is considered the main risk factor for other cardiovascular diseases and cerebrovascular accidents $[1,4,5]$. In the USA, the prevalence of $\mathrm{SH}$ in adults $\geq 20$ years is $34 \%$. In adults aged over 60 , the prevalence rises to $67 \%$ [1]. Furthermore, medication control of blood pressure in older adults is less effective than in younger individuals [3], so the use of non-pharmacological hypotensive treatments, such as physical exercises, has been recommended [6].

Several studies, including meta-analyses, have investigated the effects of physical exercise on the reduction of blood pressure in normotensive and hypertensive individuals of different age groups [6-9]. Cardiorespiratory training [CT] is known to increase the maximal oxygen consumption in older adults [10], maintain resistance to oxidative stress and improve lifestyle [11] with its effects on blood pressure, which is well established in the literature. CT is therefore suggested as a complementary treatment for hypertension [12]. The same cannot be said for resistance training (RT).

Recently, MacDonald et al. [9] carried out a meta-analysis showing that RT promoted chronic reductions in blood pressure compared with CT in middle-aged, overweight, white, pre-hypertensive women. However, this study did not involve the effects of the RT on the blood pressure of older adults, especially those who already present $\mathrm{SH}$.

The lack of systematic reviews or meta-analyses that adequately establish the chronic effects of RT on SBP and DBP in hypertensive older adults justifies this study, especially considering that it is a type of training that has been highly recommended for this age group, as it has a positive impact on the functional autonomy of this population $[13,14]$.

In older subjects, the acute effects of RT improve functional capacity [15], increase muscle strength and mass $[16,17]$, and reduce post-exercise blood pressure [18]. However, the chronic effects of RT on blood pressure in hypertensive older adults are not well established. Thus, the aim of this metaanalysis was to verify the chronic effects of RT on the systolic and diastolic blood pressure of hypertensive older adults.

\section{Methods}

This meta-analysis followed the PRISMA recommendations [19].

Protocol and Registration

A review protocol was registered in the International Prospective Register of Systematic Reviews (CRD42017072922).

Eligibility criteria

Randomized controlled trials were included in this meta-analysis to evaluate the chronic effects of resistance training (RT) on hypertensive older adults. Studies that used training protocols with less than 10 weeks, that combined aerobic training with resistance training or those without a control group (CG) were excluded. Individuals who were included in the group that did not have any type of training were considered to comprise the CG.

\section{Search strategy}

Two evaluators conducted searches independently, in April 2017, at the US National Library of Medicine (MEDLINE), Scientific Electronic Library Online (SciELO), Physiotherapy Evidence Database (PEDro), Google Scholar, Cochrane Library, Virtual Health Library (VHL), SCOPUS, SPORTDiscus and the Cumulative Index to Nursing and Allied Health Literature (CINAHL). The following descriptors were used as Medical Subject Headings (MeSH), with their respective synonyms: hypertension, elderly, and resistance training. The search phrase was obtained using the AND logic operator between the descriptors and OR between the synonyms. No language filter or time was delimited for the search. Other reviews and meta-analyses were consulted in order to find other studies, which were added manually.

\section{Data collection procedure}

The following data were extracted from the selected studies: the profile of the participants, sample size, study design, protocol of the intervention 
performed, and the SBP and DBP results, with their respective levels of significance.

Risk of bias and evaluation of the quality of the studies

To evaluate the quality of the studies, the PEDro Scale [20] of methodological evaluation was used, which consists of the sum of the scores from 11 domains, namely: 1) Eligibility of the participants; 2) Random distribution; 3) Concealed distribution; 4) Comparison of groups at baseline; 5) Blinding of participants; 6) Blinding of therapists; 7) Blinding of evaluators; 8) Measurement of at least one key outcome in $85 \%$ of subjects allocated; 9) Intention to treat; 10) Comparison between groups; 11) Measures of accuracy and variability. A study received 1 point if it met the requirement for a particular domain and 0 points if it did not. Only domain " 1 " was not included in the total score. Higher scores indicate better methodological quality of the study.

The Cochrane Scale [21, 22] was used to assess the risk of bias of the studies. Seven domains are evaluated in this scale, being classified as HIGH, UNCERTAIN or LOW risk of bias: 1) Randomization; 2) Allocation concealment; 3) Blinding of participants; 4) Blinding of evaluators; 5) Incomplete outcome data; 6) Selective reporting; 7) Other sources of bias. For a study to present a low risk of bias, all domains should receive a low risk assessment. If any domain is at "HIGH risk," the study is classified as having a "HIGH risk" of bias. In the absence of domains at "HIGH risk," the presence of at least one domain with uncertain risk implies in the classification of the study as having "UNCERTAIN risk" of bias. The publication bias was analyzed by the funnel graph.

Funnel plots were developed to detect publication bias in meta-analysis.

\section{Data Analysis}

To analyze the SBP and DBP results after the intervention of the resistance training and the control groups, the RevMan5.3 program was obtained free of charge from http://community.cochrane.org/tools/ review-production-tools/revman-5.3. The inverse variance statistical method was used, considering the SBP and DBP as continuous variables, the effect measure as the weighted mean difference and using the fixed effect analysis model. A 95\%CI was considered for the studies and for the meta-analysis, which were ordered by weight.
Level of evidence

The quality of the evidence associated with the result of each meta-analysis was assessed with the Grading of Recommendations Assessment, Development and Evaluation approach (GRADE), which indicates the confidence that can be placed in the estimate of the treatment effect [23-26].

\section{Results}

Figure 1 shows the results of the meta-analysis. A total of 1,318 articles were identified in this meta-analysis, 1,298 of them were identified through database searching, and 20 overlooked studies were identified by consulting other reviews and meta-analyses on the subject and were added manually. Then 23 duplicates were removed, and 1,290 studies were excluded after failing to meet the inclusion criteria. Five studies involving a total of 200 participants met the inclusion criteria for the meta-analysis. All of the studies had been published [or accepted for publication] in peerreviewed scientific journals.

Table 1 shows the characteristics of the studies included. Table 2 shows the RT protocols of the studies.

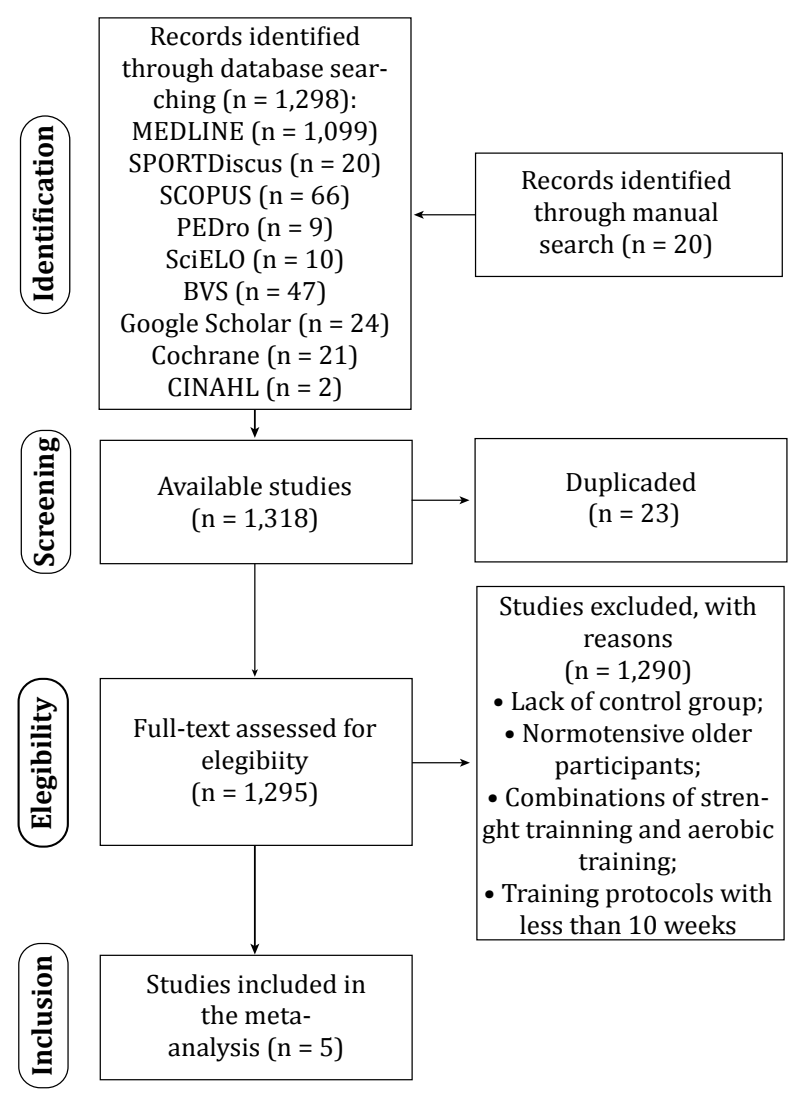

Figure 1- Flow diagram of the studies included. 
Table 1 - Characteristics of the studies included

\begin{tabular}{|c|c|c|}
\hline Study/year & Sample & Results of the variables \\
\hline $\begin{array}{l}\text { Terra et al., } 2008 \\
\text { [27] }\end{array}$ & $\begin{array}{l}n=52 \text { hypertensive older women, } \\
\text { controlled with antihypertensive } \\
\text { medication } \\
\text { Age: } 65.9 \pm 4.5 \text { years. }\end{array}$ & $\begin{array}{l}\text { RTG: } \\
\text { SBP }(m m H g) \text { : Pre-training: } 125.2 \pm 9.3 \text {; Post-training: } 114.7 \pm 9.2(p=0.01 \\
\text { intragroup and pre x post) / } p<0.01 \text { intergroup; } \\
\text { DBP(mmHg): Pre-training: } 72.0 \pm 6.8 \text {; Post-training: } 71.04 \pm 7.9(p=0.3) / \\
p>0.05 \text { intergroup. } \\
\text { CG: No difference was found. } \\
\text { SBP(mmHg): Pre-training: } 124.6 \pm 10.1 \text {; Post-training: } 123.3 \pm 13.5 ; \\
\text { DBP(mmHg): Pre-training: } 74.2 \pm 7.3 \text {; Post-training: } 73.3 \pm 7.5 .\end{array}$ \\
\hline $\begin{array}{l}\text { Gonçalves et al., } \\
2014 \text { [28] }\end{array}$ & $\begin{array}{l}n=17 \text { hypertensive older adults, } \\
\text { controlled with antihypertensive } \\
\text { medication, nonsmokers and with } \\
\text { sedentary lifestyle for more than six } \\
\text { months ( }>60 \text { years) } \\
\text { Age: } R T G=65.6 \pm 1.9 \text {; and } \\
\text { CG }=66.1 \pm 1.2 \text { years. }\end{array}$ & $\begin{array}{l}\text { RTG: } \\
\text { SBP }(m m H g): \text { Pre-training: } 126.0 \pm 5.2 ; \text { Post-training: } 122.9 \pm 4.49 \\
(p=0.10) ; \text { DBP }(m m H g): \text { Pre-training: } 80.9 \pm 3.3 ; \text { Post-training: } 81.9 \pm 4.4 \\
(p=0.08) ; \\
\text { CG: } \\
\text { SBP }(m m H g): \text { Pre-training: } 137.0 \pm 5.0 ; \text { Post-training: } 134.9 \pm 4.5 ; \\
\text { DBP(mmHg): Pre-training: } 88.3 \pm 2.6 ; \text { Post-training: } 88.7 \pm 2.7 ;\end{array}$ \\
\hline $\begin{array}{l}\text { Mota et al., } 2013 \\
\text { [29] }\end{array}$ & $\begin{array}{l}n=64 \text { hypertensive older adults with } \\
\text { sedentary lifestyle for more than } 6 \\
\text { months, hypertension controlled with } \\
\text { antihypertensive medication. } \\
\text { Age: } 67.1 \pm 6.2 \text { years. }\end{array}$ & $\begin{array}{l}\text { RTG: } \\
\text { SBP (mmHg): Pre-training: } 134.5 \pm 14.6 \text {; Post-training: } 120.2 \pm 11.8 \\
\text { (p < } 0.05 \text { intergroup from the } 3^{\text {rd }} \text { week); } \\
\text { DBP (mmHg): Pre-training: } 76.0 \pm 9.2 \text {; Post-training: } 72.4 \pm 9.3(p<0.05 \\
\text { intragroup and } p>0.05 \text { intergroup). } \\
\text { CG: } \\
\text { SBP (mmHg): Pre-training: } 131.8 \pm 16.9 \text {; Post-training: } 132.3 \pm 17.6 ; \\
(p>0.05) \\
\text { DBP (mmHg): Pre-training: } 74.3 \pm 7.4 ; \text { Post-training: } 73.8 \pm 7.8(p>0.05)\end{array}$ \\
\hline $\begin{array}{l}\text { Dantas et al., } \\
2016 \text { [10] }\end{array}$ & $\begin{array}{l}n=25 \text { sedentary hypertensive } \\
\text { older women, controlled with } \\
\text { antihypertensive medication, aged } \\
\text { between } 60 \text { and } 75 \text { years; } \\
\text { Age: } 64.7 \pm 4.7 \text { years (RTG) and } \\
67.7 \pm 5.6 \text { years (CG). }\end{array}$ & $\begin{array}{l}\text { RTG: } \\
\text { SBP }(\mathrm{mmHg}) \text { : pre-training: } 142.9 \pm 13.1 \text {; Post-training }=137.1 \pm 12.2 \\
\text { DBP(mmHg): pre-training: } 68.2 \pm 6.2 \text {; post-training: } 64.9 \pm 5.1 \\
\text { CG: } \\
\text { SBP }(\mathrm{mmHg}) \text { : pre-training }=139.9 \pm 10.3 \text {; post-training: } 144.9 \pm 14.1 \\
(p=0.050 \text { intergroup) } \\
\text { DBP(mmH): pre-training: } 67.4 \pm 9.5 \text {; post-training: } 72.0 \pm 7.7(p=0.016 \\
\text { intergroup) }\end{array}$ \\
\hline $\begin{array}{l}\text { Heffernan et al., } \\
2013 \text { [30] }\end{array}$ & $\begin{array}{l}n=21 \text { participants with pre- } \\
\text { hypertension or hypertension without } \\
\text { treatment. } \\
\text { Age: } 61 \pm 1 \text { years }\end{array}$ & $\begin{array}{l}\text { RTG: } \\
\text { SBP }(\mathrm{mmHg}) \text { : pre-training }=140 \pm 4 ; \text { post-training }=134 \pm 4 \\
\text { DBP }(\mathrm{mmHg}) \text { : pre-training }=83 \pm 2 ; \text { post-training }=77 \pm 2 \text {; } \\
\text { CG: } \\
\text { SBP }(\mathrm{mmHg}) \text { : pre-training }=136 \pm 4 ; \text { post-training: } 139 \pm 4 \text {; } \\
\text { DBP }(\mathrm{mmH}) \text { : pre-training }=86 \pm 2 ; \text { post-training }=82 \pm 2\end{array}$ \\
\hline
\end{tabular}

Note: $n$ = sample size; $\mathrm{CG}=$ control group; $\mathrm{RTG}=$ resistance training group; $\mathrm{SBP}=$ systolic blood pressure; $\mathrm{DBP}=$ diastolic blood pressure.

Table 2 - Resistance training protocols of the studies

\begin{tabular}{|c|c|c|c|c|c|c|}
\hline Study & Exercises & Familiarization & $\begin{array}{l}\text { Duration } \\
\text { (weeks) }\end{array}$ & $\begin{array}{c}\text { Weekly } \\
\text { frequency }\end{array}$ & Intensity & Protocol \\
\hline $\begin{array}{l}\text { Terra et al., } \\
2008 \text { [27] }\end{array}$ & $\begin{array}{l}\text { Lateral pulldown, knee } \\
\text { extension, chest press, leg } \\
\text { abduction, knee flexion, } \\
\text { shoulder abduction with } \\
\text { dumbbell, standing calf } \\
\text { raise, abdominal exercises, } \\
\text { trunk extension, and } \\
\text { 45-degree leg press. }\end{array}$ & No & 12 & $\begin{array}{l}3 \times \text { per } \\
\text { week on } \\
\text { alternate } \\
\text { days }\end{array}$ & $\begin{array}{l}\text { Weeks 1-4: } 60 \% \text { of } 1-\mathrm{RM} \text {; } \\
\text { Weeks 5-8: } 70 \% \text { of 1-RM; } \\
\text { Weeks 9-12: } 80 \% \text { of } 1-\mathrm{RM} \text {; }\end{array}$ & $\begin{array}{l}3 \text { sets of } 12,10 \text { and } 8 \\
\text { repetitions. }\end{array}$ \\
\hline $\begin{array}{l}\text { Gonçalves } \\
\text { et al., } \\
2014 \text { [28] }\end{array}$ & $\begin{array}{l}\text { Vertical bench press, leg } \\
\text { extension, front pull with } \\
\text { high pulley, leg curl, barbell } \\
\text { curls on Scott bench, } \\
\text { seated calf raise, triceps } \\
\text { pulley, and crunch. }\end{array}$ & 2 weeks & 12 & $\begin{array}{l}\text { 3x per } \\
\text { week }\end{array}$ & $\begin{array}{l}\text { The initial load of } 40 \% \\
\text { of } 1 \text {-RM (increased } \\
\text { individually each week } \\
\text { for perceived exertion to } \\
\text { be between "mild" and } \\
\text { "moderate." }\end{array}$ & $\begin{array}{l}2 \text { sets of } 15 \\
\text { repetitions, except calf } \\
\text { muscle exercises (2 } \\
\text { sets } x 20 \text { reps) and } \\
\text { crunch (2 sets x } 30 \\
\text { reps); } 1: 2 \text { ratio. }\end{array}$ \\
\hline
\end{tabular}

(To be continued) 
(Conclusion)

\begin{tabular}{|c|c|c|c|c|c|c|}
\hline Study & Exercises & Familiarization & $\begin{array}{l}\text { Duration } \\
\text { (weeks) }\end{array}$ & $\begin{array}{c}\text { Weekly } \\
\text { frequency }\end{array}$ & Intensity & Protocol \\
\hline \multirow{3}{*}{$\begin{array}{l}\text { Mota et } \\
\text { al., } 2013 \\
{[29]}\end{array}$} & \multirow{3}{*}{$\begin{array}{l}\text { Knee flexion, shoulder } \\
\text { abduction with free } \\
\text { weights, independent } \\
\text { calf lift, crunch, trunk } \\
\text { extension, and 45-degree } \\
\text { leg press; }\end{array}$} & $\begin{array}{l}\text { Yes (1 month) } \\
12 \text { low-intensity } \\
\text { exercise }\end{array}$ & \multirow{3}{*}{16} & \multirow{3}{*}{$\begin{array}{l}3 \times \text { per } \\
\text { week }\end{array}$} & $60 \%$ of $1-\mathrm{RM} ;$ & $\begin{array}{l}3 \text { sets, } 12 \text { repetitions } \\
\text { and } 60 " \text { rest interval } \\
\text { between sets. }\end{array}$ \\
\hline & & \multirow{2}{*}{$\begin{array}{l}\text { sessions, } \\
\text { performing ten } \\
\text { repetitions in } \\
\text { each set with } \\
\text { a } 30 \text {-second } \\
\text { interval between } \\
\text { sets. }\end{array}$} & & & $70 \%$ of $1-\mathrm{RM}$ & $\begin{array}{l}3 \text { sets, } 10 \text { repetitions } \\
\text { with } 60 \text { " rest interval } \\
\text { between sets. }\end{array}$ \\
\hline & & & & & $80 \%$ of $1-\mathrm{RM}$; & $\begin{array}{l}3 \text { sets, } 8 \text { repetitions } \\
\text { with } 90 " \text { rest interval } \\
\text { between sets. }\end{array}$ \\
\hline \multirow{6}{*}{$\begin{array}{l}\text { Dantas et } \\
\text { al., } 2016 \\
{[10]}\end{array}$} & \multirow{6}{*}{$\begin{array}{l}\text { Leg press; rowing } \\
\text { machine; trunk flexion; } \\
\text { knee flexion, bench press, } \\
\text { trunk extension, push } \\
\text { press, plantar flexion, and } \\
\text { front pull. }\end{array}$} & & & $\begin{array}{l}\text { 2x per } \\
\text { week }\end{array}$ & \multirow{6}{*}{${ }^{*} \mathrm{PES}=5-7$} & $\begin{array}{l}1 \text { set, } 9-11 \\
\text { repetitions; } 120 " \\
\text { interval between sets; }\end{array}$ \\
\hline & & & & $\begin{array}{l}2 x \text { per } \\
\text { week }\end{array}$ & & $\begin{array}{l}2 \text { sets, } 9-11 \\
\text { repetitions; } 120 " \\
\text { interval between sets; }\end{array}$ \\
\hline & & & & $\begin{array}{l}2 \times \text { per } \\
\text { week }\end{array}$ & & $\begin{array}{l}2 \text { sets, } 11-13 \\
\text { repetitions; } 90 " \\
\text { interval between sets; }\end{array}$ \\
\hline & & & & $\begin{array}{l}3 \times \text { per } \\
\text { week }\end{array}$ & & $\begin{array}{l}2 \text { sets, } 11-13 \\
\text { repetitions; } 90 " \\
\text { interval between sets; }\end{array}$ \\
\hline & & & & $\begin{array}{l}3 \times \text { per } \\
\text { week }\end{array}$ & & $\begin{array}{l}3 \text { sets, } 11-13 \\
\text { repetitions; } 90 " \\
\text { interval between sets; }\end{array}$ \\
\hline & & & & $\begin{array}{l}3 x \text { per } \\
\text { week }\end{array}$ & & $\begin{array}{l}\text { Weeks } 9-11: 3 \text { sets, } \\
\text { 13- } 15 \text { repetitions; } 60 \text { " } \\
\text { interval between sets; }\end{array}$ \\
\hline $\begin{array}{l}\text { Heffernan } \\
\text { et al., } \\
2013 \text { [30] }\end{array}$ & $\begin{array}{l}\text { Vertical bench press, front } \\
\text { pull, paddling, biceps curl, } \\
\text { leg press, knee extension, } \\
\text { knee flexion, crunch, and } \\
\text { trunk extension; }\end{array}$ & No & 12 & $\begin{array}{l}3 \times \text { per } \\
\text { week }\end{array}$ & $\begin{array}{l}\text { Initial load: } 40 \% \text { of 1-RM } \\
\text { for MMSS and } 60 \% \text { for } \\
\text { MMIl; } \\
\text { The load increased } 5 \% \\
\text { every } 3 \text { weeks, until } \\
\text { subjects could easily } \\
\text { perform } 15 \text { repetitions. }\end{array}$ & $\begin{array}{l}2 \text { sets of } 12-15 \\
\text { repetitions. }\end{array}$ \\
\hline
\end{tabular}

Note: $\mathrm{RTG}=$ resistance training group; 1 -RM = one-repetition-maximum; $\mathrm{PES}{ }^{*}-$ Perceived Exertion Scale (OMNI-RES) adapted for strength training.

Table 3 shows the methodological quality of the studies. The score in the PEDro Scale ranged from 3 to 7 points. Table 4 shows the risk of bias evaluated with Cochrane Scale. Two studies presented high risk
$[27,29]$; two presented uncertain risk [28, 30]; and one presented low risk of bias [10]. Most of the studies failed to comply with the domains "randomization" and "allocation concealment."

Table 3 - Methodological quality of the studies

\begin{tabular}{lcccccccccccc}
\hline Study & $\mathbf{1}$ & $\mathbf{2}$ & $\mathbf{3}$ & $\mathbf{4}$ & $\mathbf{5}$ & $\mathbf{6}$ & $\mathbf{7}$ & $\mathbf{8}$ & $\mathbf{9}$ & $\mathbf{1 0}$ & $\mathbf{1 1}$ & Score \\
\hline Dantas et al. (2016) [10] & 1 & 1 & 1 & 1 & 0 & 0 & 0 & 1 & 1 & 1 & 1 & $7 / 10$ \\
Heffernan et al (2013) [30] & 1 & 1 & 0 & 1 & 0 & 0 & 0 & 1 & 1 & 1 & 1 & $6 / 10$ \\
Terra et al. (2008) [27] & 1 & 0 & 0 & 1 & 0 & 0 & 0 & 1 & 1 & 1 & 1 & $5 / 10$ \\
Mota et al. (2013) [29] & 1 & 0 & 0 & 1 & 0 & 0 & 0 & 1 & 1 & 1 & 1 & $5 / 10$ \\
Gonçalves et al (2014) [28] & 0 & 1 & 0 & 0 & 0 & 0 & 0 & 0 & 0 & 1 & 1 & $3 / 10$ \\
\hline
\end{tabular}

Note: 1) Eligibility of the participants; 2) Random distribution; 3) Concealed distribution; 4) Comparison of groups at baseline; 5) Blinding of participants; 6) Blinding of therapists; 7) Blinding of evaluators; 8) Measurement of at least one key outcome in $85 \%$ of subjects allocated; 9) Intention to treat; 10) Comparison between groups; 11) Measures of accuracy and variability. 
Table 4 - Risk of bias analysis of the studies

\begin{tabular}{lccccccccc}
\hline Author/year & $\mathbf{1}$ & $\mathbf{2}$ & $\mathbf{3}$ & $\mathbf{4}$ & $\mathbf{5}$ & $\mathbf{6}$ & $\mathbf{7}$ & Risk \\
\hline Terra et al. (2008) [27] & High & High & Low & Low* & Low & Low & Low & High \\
Dantas et al. (2016) [10] & Low & Low & Low & Low* & Low & Low & Low & Low \\
Gonçalves et al (2014) [28] & Uncertain & Uncertain & Low* & Low* & Uncertain & Low & Low & Uncertain \\
Mota et al. (2013) [29] & High & High & Low* & Low* & Low & Low & Low & High \\
Heffernan et al (2013) [30] & Uncertain & Uncertain & Low & Low* & Low & Low & Uncertain & Uncertain
\end{tabular}

Note: 1) Randomization; 2) Allocation concealment; 3) Blinding of participants; 4) Blinding of evaluators; 5) Incomplete outcome data; 6) Selective reporting; 7) Other sources of bias. * Domain characterized with low risk due to the impossibility of blinding the RT participants and evaluators.

The meta-analysis (Figure 2) of 96 participants in the intervention group and 104 in the control group showed that RT reduces $7.26 \mathrm{mmHg}$ $(95 \% \mathrm{CI}=-7.26,-5.37)$ in SBP and 4.84 in DBP $(95 \% \mathrm{CI}=-5.89,-3,79)$. Publication bias was not suspected in the meta-analysis since there was a symmetrical scatter of the studies in the funnel plot (Figure 3).

Using the GRADE approach, the overall quality of evidence was low (Table 5).

(A)

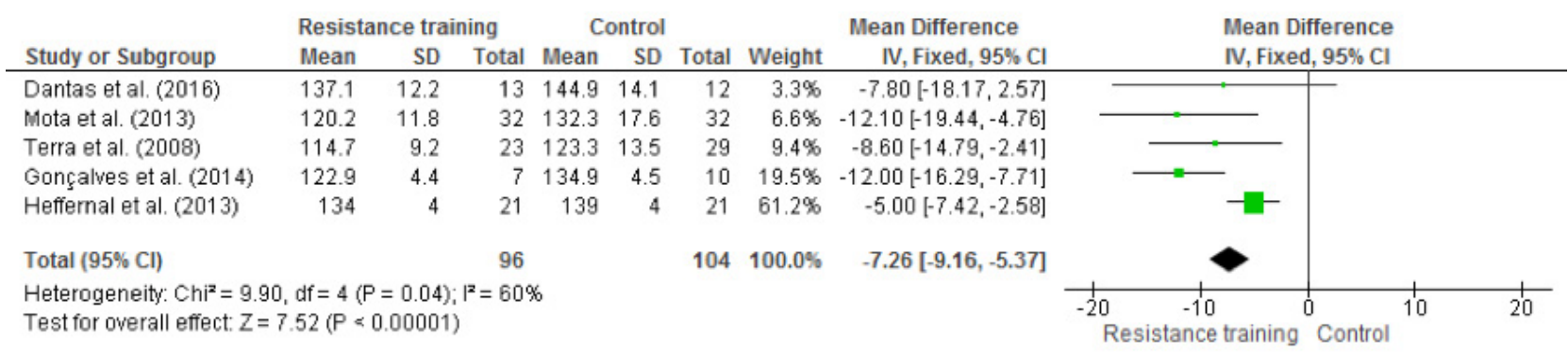

(B)

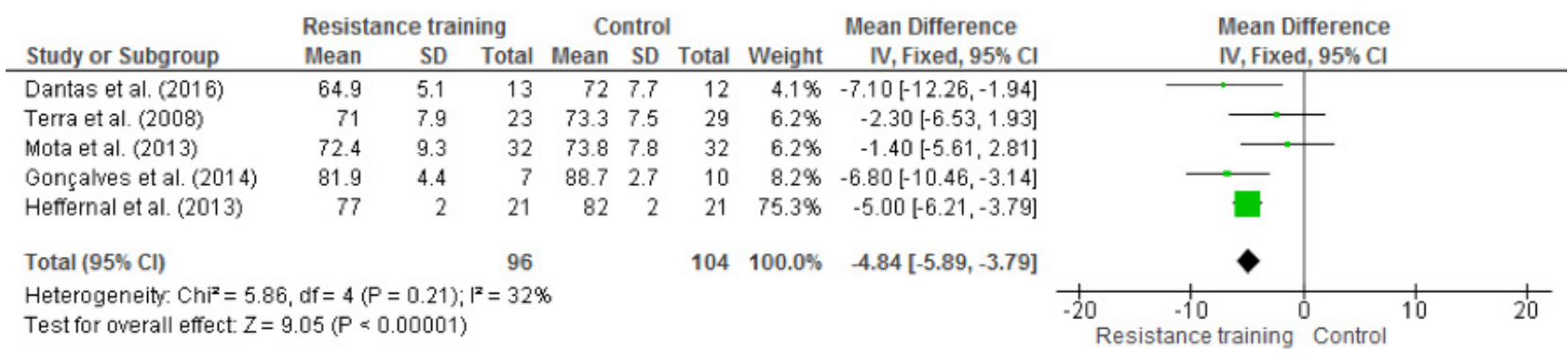

Figure 2 - Meta-analysis results of the effects of resistance training on blood pressure of hypertensive older adults: (A) systolic blood pressure (SBP); (B) diastolic blood pressure (DBP). 
(A)

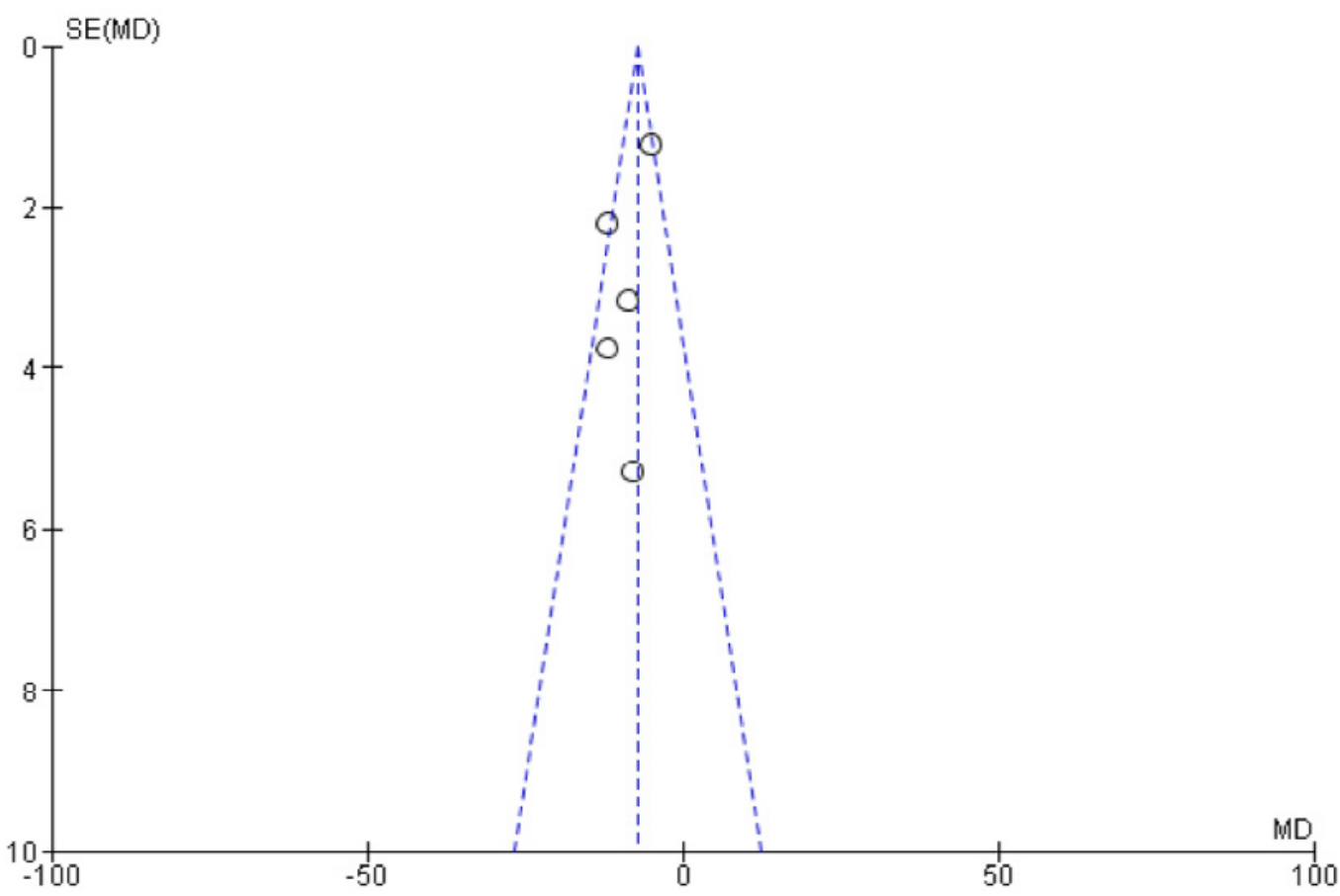

(B)

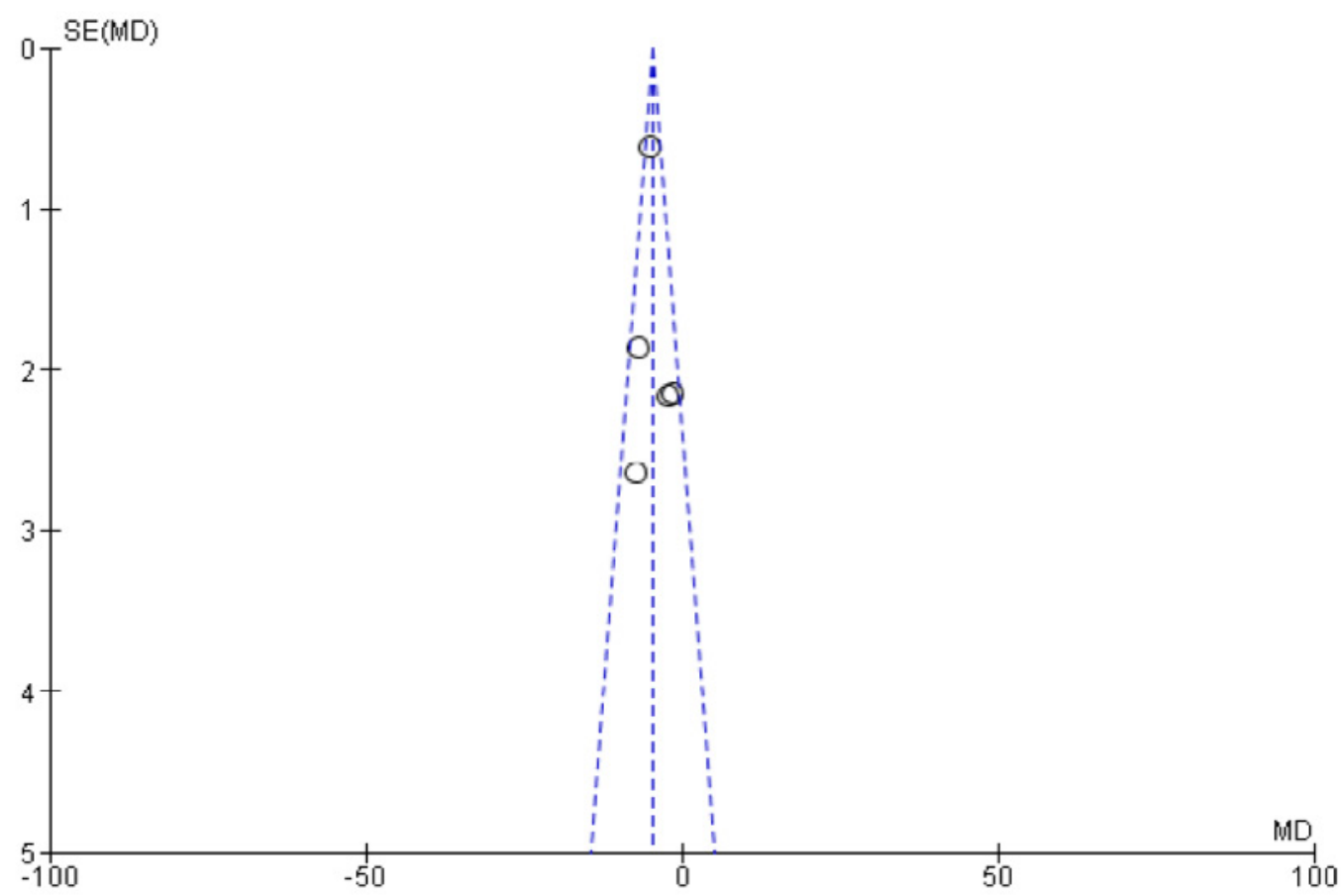

Figure 3 - Funnel chart for the effects of resistance training on blood pressure of hypertensive older adults: (A) systolic blood pressure (SBP); (B) diastolic blood pressure (DBP). 
Table 5 - Level of evidence with Grading of Recommendations Assessment, Development and Evaluation of the metaanalysis (GRADE)

\begin{tabular}{|c|c|c|c|c|c|c|c|c|c|c|c|c|}
\hline \multicolumn{7}{|c|}{ Certainty assessment } & \multicolumn{2}{|c|}{$\begin{array}{c}\text { No. of } \\
\text { patients }\end{array}$} & \multicolumn{2}{|c|}{ Effect } & \multicolumn{2}{|c|}{ Certainty Importance } \\
\hline $\begin{array}{l}\text { No. of } \\
\text { studies }\end{array}$ & $\begin{array}{l}\text { Study } \\
\text { design }\end{array}$ & $\begin{array}{c}\text { Risk of } \\
\text { bias }\end{array}$ & Inconsistency & Indirectness & Imprecision & $\begin{array}{c}\text { Other } \\
\text { considerations }\end{array}$ & RT & CG & $\begin{array}{l}\text { Relative } \\
(95 \% \mathrm{Cl})\end{array}$ & $\begin{array}{l}\text { Absolute } \\
(95 \% \mathrm{CI})\end{array}$ & & \\
\hline SBP & & & & & & & & & & & & \\
\hline 5 & $\begin{array}{l}\text { random- } \\
\text { ized trials }\end{array}$ & $\begin{array}{l}\text { very } \\
\text { serious }\end{array}$ & not serious & not serious & not serious & none & 96 & 104 & - & $\begin{array}{c}\text { mean } \\
\text { 7.26 } \mathrm{mmHg} \\
\text { (9.16 higher } \\
\text { to } 5.37 \\
\text { higher) }\end{array}$ & $\underset{\text { LOW }}{\oplus \oplus \bigcirc \bigcirc}$ & CRITICAL \\
\hline DBP & & & & & & & & & & & & \\
\hline 5 & $\begin{array}{l}\text { random- } \\
\text { ized trials }\end{array}$ & $\begin{array}{l}\text { very } \\
\text { serious }\end{array}$ & not serious & not serious & not serious & none & 96 & 104 & - & $\begin{array}{c}\text { mean } \\
4.84 \mathrm{mmHg} \\
\text { (5.89 higher } \\
\text { to } 3.79 \\
\text { higher) }\end{array}$ & $\underset{\text { LOW }}{\oplus \bigcirc \bigcirc}$ & CRITICAL \\
\hline
\end{tabular}

\section{Discussion}

This meta-analysis showed that the regular practice of RT from 12 to 16 weeks, three times a week, with three sets of 8-12 repetitions at an intensity from $60 \%$ to $80 \%$ of $1-\mathrm{RM}$, significantly reduced systolic blood pressure (SBP) by $7.26 \mathrm{mmHg}$ and diastolic blood pressure (DBP) by $4.84 \mathrm{mmHg}$ (Figure 2).

Hypertension is widely associated with increased cardiovascular disease, and physical exercise is recommended as a strategy for the prevention and treatment of these diseases [31].

The guideline on lifestyle management to reduce cardiovascular risk published by the American Heart Association and American College of Cardiology highlights an association between higher levels of physical exercise, lower rates of chronic noncommunicable diseases, and increased longevity [32]. The document shows the effect of CT on blood pressure in adults (including hypertensive individuals) reduces SBP by an average of $2-5 \mathrm{mmHg}$ and DBP by 1-4 mmHg over at least 12 weeks of intervention, and RT does not present similar evidence consistently. Therefore, only aerobic physical exercises are recommended to reduce blood pressure, which should be performed at moderate to vigorous intensity, three to four times a week, in sessions with an average duration of 40 minutes.

Corroborating the recommendations of the American Heart Association and the American College of Cardiology, the Brazilian Society of Cardiology, in its $7^{\text {th }}$ Brazilian Guideline of Arterial Hypertension, also presents physical exercise as a non-medication treatment, emphasizing CT as preferential for this purpose, claiming that RT reduces the blood pressure of pre-hypertensive patients; however, it has no effect on hypertensive patients [33]. According to these guidelines, $\mathrm{CT}$ reduces $\pm 2.1 \mathrm{mmHg}$ in SBP and $1.7 \mathrm{mmHg}$ in DBP in pre-hypertensive patients and $\pm 8.3 \mathrm{mmHg}$ in SBP and $5.2 \mathrm{mmHg}$ in DBP in hypertensive patients, while RT reduces $\pm 4.0 \mathrm{mmHg}$ in SBP and $3.8 \mathrm{mmHg}$ in DBP in pre-hypertensive patients, with no reductions in hypertensive individuals.

Contradicting the positions described above, McDonald et al. [9] performed a meta-analysis to provide accurate estimates of the efficacy of dynamic RT as an autonomous antihypertensive therapy for adults (47.2 \pm 19 years). The authors found reductions of $3.0 \mathrm{mmHg}$ in SBP and $2.1 \mathrm{mmHg}$ in DBP; greater SBP reductions were found in studies with non-white samples and with those who were not taking medication; greater reductions in DBP were found in studies with samples that presented higher DBP at rest $(5.2 \approx \mathrm{mmHg}$ in hypertensive patients, $3.3 \mathrm{mmHg}$ in pre-hypertensive patients, $1.0 \mathrm{mmHg}$ in normotensive patients), and with samples that did not take medication. Data showed that the dose-response relationship of RT reduces blood pressure more than that of CT. It is noteworthy that this meta-analysis involved studies with young adults ( $47.2 \pm 19.0$ years) and little is known about the effect of the RT on the blood pressure of hypertensive older adults.

The evidence found in this meta-analysis does not corroborate the positions of the American Heart 
Association, American College of Cardiology or the $7^{\text {th }}$ Brazilian Guideline of Arterial Hypertension, being more in line with the findings of McDonald et al. [9], who found reductions in both SBP and DBP in young adults. These significant reductions in SBP and DBP after RT can be explained due to the responses of the cardiorespiratory system to exercise, as the increase in energy demand also increases heart rate, systolic volume and, consequently, decreases peripheral vascular resistance due to the release of nitric oxide into the bloodstream; thus reducing blood pressure as the final result [34]. Although some types of training may be more effective in triggering such responses, such as CT in younger people [35], in general, any physical exercise will produce them, stimulating the cardiorespiratory system to promote greater responses (consequently, greater reductions in arterial pressure). Considering this study showed a similar reduction in blood pressure to that of aerobic exercise, we can deduce that RT affects this system, at least in older adults, corroborating the findings of Silva et al., 2016 [36] and Silva \& Farinatti, 2012 [37].

Observing the studies that are part of this metaanalysis, the adjustment of the training load was performed by the perceived exertion scale (PSE) or by the percentage of the result in the test of a maximum resistance [1-RM] (Table 2). To obtain the chronic effects of $\mathrm{BP}$ reduction is essential, and the one that controls the load by the 1-RM test is indicated between the two forms mentioned above, since it is a valid [38] and reliable [39] tool. There is still no consensus regarding the optimal dose to achieve the best possible response of lowering blood pressure in older adults, or the best combination of RT variables (volume $\mathrm{x}$ intensity); however, studies suggest a low to moderate intensity [40]. This fact reveals another gap to be investigated in future studies. Furthermore, the impact of resistance training on the cardiorespiratory capacity and autonomic response should be investigated, considering that these mechanisms affect the clinical framework of hypertension [41].

Muscular strength tends to decrease throughout the aging process, which is strongly related to the loss of the functional capacity in older adults [42]. Thus, interventions to train this physical capacity are important to present the possibility of positively affecting the functional autonomy $[13,14]$. Considering the generally low adherence to physical exercise in this population [43], a single modality that promotes beneficial effects both in autonomy and in the reduction of blood pressure, such as RT, can present a promising non-medication therapy.

Except for the study by Gonçalves et al. [28], the other four studies of this meta-analysis presented a score of 5.0 or more on the PEDro Scale. If we consider that it is impossible to fulfill criteria 5 and 6 of the Scale for this type of study, this meta-analysis showed a good methodological quality, which contributed substantially to the internal validity of this study (Table 2). In contrast, a high risk of bias was prevalent, as three of the four studies that randomly allocated the older adults into the groups did not report how this randomization was performed.

Despite the evidence presented here, the affirmation that RT has a positive impact on the reduction of SBP and DBP at rest in older adults should be viewed with caution, since, of the 1,318 studies found, only 5 were selected for this metaanalysis. The restriction criteria adopted led to the exclusion of 1,290 studies, showing the need for more randomized controlled trials investigating RT and systemic hypertension (Figure 1). Due to the low level of evidence, a new research may change the results found. Further studies on the subject are recommended (Table 5).

Although the authors of the studies selected for this meta-analysis ensured that the older adults were hypertensive, the initial values (pre-training) of SBP and DBP were below 150 and $90 \mathrm{mmHg}$, respectively (Table 1), which characterized a state of normotension, as the older participants in the studies had their blood pressure controlled through medication. However, the presence of an inactive control group in all the studies could be a confounding factor of the results found in this meta-analysis. It is also noteworthy that hypertensive older adults almost always control their blood pressure with medication due to medical recommendations.

\section{Conclusion}

RT was effective in reducing the blood pressure of controlled hypertensive older adults. The action of medication on blood pressure, which could be a confounding factor of the results, was controlled by the presence of an inactive control group in all studies included in this meta-analysis. The results of this meta-analysis are relevant and have a great practical implication, since muscular strength tends to decrease throughout the aging process. Therefore, RT can affect 
the functional autonomy and, probably, decrease the blood pressure of this population. A single modality that promotes beneficial effects both in autonomy and in the reduction of blood pressure, presents itself as a promising non-medication therapy. Furthermore, considering the functional, organic and biological conditions of older adults, these results imply a higher survival rate in this population, as well as a possible decrease in the need for medication inherent to hypertension.

\section{References}

1. Benjamin EJ, Blaha MJ, Chiuve SE, Cushman M, Das SR, Deo R, et al. Heart Disease and Stroke Statistics - 2017 Update - A Report From the American Heart Association. Circulation. 2017;135(10).

2. James PA, Oparil S, Carter BL, Cushman WC, DennisonHimmelfarb C, Handler J, et al. 2014 Evidence-Based Guideline for the Management of High Blood Pressure in Adults: Report From the Panel Members Appointed to the Eighth Joint National Committee (JNC 8). JAMA. 2014;311(5):507-20.

3. Yoon S, Carroll MD, Fryar CD. Hypertension Prevalence and Control Among Adults: United States, 2011-2014. NCHS Data Brief. 2015;220:1-8.

4. Chowdhury EK, Jennings GLR, Dewar E, Wing LMH, Reid CM, ANBP2 Echo Study Committee. Predictive Performance of Echocardiographic Parameters for Cardiovascular Events Among Elderly Treated Hypertensive Patients. Am J Hypertens. 2016;29(7):821-31.

5. García M, Bastian B, Rossen M, Anderson R, Miniño A, Yoon P, et al. Potentially Preventable Deaths Among the Five Leading Causes of Death - United Statets, 2010 and 2014. MMWR Morb Mortal Wkly Rep. 2016;65(45):1245-55.

6. Börjesson M, Onerup A, Lundqvist S, Dahlöf B. Physical activity and exercise lower blood pressure in individuals with hypertension: narrative review of 27 RCTs. Br J Sports Med. 2016;50(6):356-61.

7. Carpio-Rivera E, Moncada-Jiménez J, Salazar-Rojas W, Solera-Herrera A. Acute effects of exercise on blood pressure: A meta-analytic investigation. Arq Bras Cardiol. 2015;106(5):422-33.
8. Cornelissen VA, Smart NA. Exercise training for blood pressure: a systematic review and meta-analysis. J Am Heart Assoc. 2012;2(1):1-9.

9. MacDonald HV, Johnson BT, Huedo-Medina TB, Livingston J, Forsyth KC, Kraemer WJ, et al. Dynamic Resistance Training as Stand-Alone Antihypertensive Lifestyle Therapy: A Meta-Analysis. J Am Heart Assoc. 2016;5(10):1-48.

10. Dantas FFO, Brasileiro-Santos MS, Batista RMF, Nascimento LS, Castellano LRC, Ritti-Dias RM, et al. Effect of Strength Training on Oxidative Stress and the Correlation of the Same with Forearm Vasodilatation and Blood Pressure of Hypertensive Elderly Women: A Randomized Clinical Trial. PloS One. 2016;(2):1-19.

11. Mancia G, Fagard R, Narckiewics K, Redon J, Zanchetti A, Böhm, et al. 2013 ESH/ESC Guidelines for the management of arterial hypertension: the Task Force for the Management of Arterial Hypertension of the European Society of Hypertension (ESH) and of the European Society of Cardiology (ESC). Eur Heart J. 2013;34(28):1281-357.

12. Larsen MK, Matchkov VV. Hypertension and physical exercise: The role of oxidative stress. Medicina (Kaunas). 2016;52(1):19-27.

13. Mazini Filho ML, Vianna JM, Venturini GRO, Matos DG, Ferreira MEC. Avaliação de diferentes programas de exercícios físicos na força muscular e autonomia funcional de idosas. Motricidade. 2016;12(S2):124-33.

14. Matos D, Manzini Filho ML, Moreira OC, Oliveira CE, Oliveira Venturini GR, Silva-Gricoletto ME, et al. Effects of eight weeks of functional training in the functional autonomy of elderly women. J Sports Med Phys Fitness. 2017;57(3):272-7.

15. Tiggemann CL, Dias CP, Radaelli R, Massa JC, Bortoluzzi R, Schoenell MC, et al. Effect of traditional resistance and power training using rated perceived exertion for enhancement of muscle strength, power, and functional performance. Age (Dordr). 2016;38(2):42.

16. Chen HT, Chung YC, Chen YJ, Ho SY, Wu HJ. Effects of Different Types of Exercise on Body Composition, Muscle Strength, and IGF-1 in the Elderly with Sarcopenic. J Am Geriatr Soc. 2017;65(4):827-32. 
17. Csapo R, Alegre LM. Effects of resistance training with moderate vs heavy loads on muscle mass and strength in the elderly: A meta-analysis. Scand J Med Sci Sports. 2015;26(9)995-1006.

18. Brito AF, Oliveira CVC, Brasileiro-Santos MS, Santos AC. Resistance exercise with different volumes: blood pressure response and forearm blood flow in the hypertensive elderly. Clin Interv Aging 2014;9:2151-8.

19. Moher D, Liberati A, Tetzlaff J, Altman DG, The PRISMA Group. Preferred Reporting Items for Systematic Reviews and Meta-Analyses: The PRISMA Statement (Reprinted from Annals of Internal Medicine). Phys Ther. 2009;89(9):873-80.

20. Shiwa SR, Costa LOP, Moser ADL, Aguiar IC, Oliveira LVF. PEDro: a base de dados de evidências em fisioterapia. Fisioter Mov. 2011;24(3):523-33.

21. Higgins JPT, Altman DG, Gøtzsche PC, Jüni P, Moher D, Oxman AD, et al. The Cochrane Collaboration's tool for assessing risk of bias in randomised trials. BMJ. 2011;343:1-9.

22. Carvalho APV, Silva V, Grande AJ. Avaliação do risco de viés de ensaios clínicos randomizados pela ferramenta da colaboração Cochrane. Diagn Tratamento. 2013;18(1):38-44.

23. Guyatt GH, Oxman AD, Kunz R, Brozek J, AlonsoCoello P, Rind D, et al. GRADE guidelines 6. Rating the quality of evidence - Imprecision. J Clin Epidemiol. 2011;64(12):1283-93.

24. Guyatt GH, Oxman AD, Montori V, Vist G, Kunz R, Brozek J, et al. GRADE guidelines: 5. Rating the quality of evidence - publication bias. J Clin Epidemiol. 2011;64(12):1277-82.

25. Guyatt GH, Oxman AD, Kunz R, Woodcock J, Brozek J, Helfand M, et al. GRADE guidelines: 7. Rating the quality of evidence - inconsistency. J Clin Epidemiol. 2011;64(12):1294-302.

26. Guyatt GH, Oxman AD, Kunz R, Woodcock J, Brozek J, Helfand M, et al. GRADE guidelines: 8. Rating the quality of evidence - indirectness. J Clin Epidemiol. 2011;64(12):1303-10.
27. Terra DF, Mota MR, Rabelo HT, Bezerra LM, Lima RM, Ribeiro AG, et al. Reduction of arterial pressure and double product at rest after resistance exercise training in elderly hypertensive women. Arq Bras Cardiol. 2008;91(5):299-305.

28. Gonçalves CGS, Nakamura FY, Gerage AM, Januário RSB, Nascimento MA, Farinatti TV, et al. Functional and physiological effects of a 12-week programme of resistance training in elderly hypertensive. INT SPORTMED J. 2014;15(1):50-61.

29. Mota MR, Oliveira RJ, Dutra MT, Pardono E, Terra DF, Lima RM, et al. Acute and chronic effects of exercise on blood pressure in hypertensive elderly women. J Strength Cond Res. 2013;27(12):3475-80.

30. Heffernan KS, Yoon ES, Sharman JE, Davies JE, Shih YT, Chen $\mathrm{CH}$, et al. Resistance exercise training reduces arterial reservoir pressure in older adults with prehypertension and hypertension. Hypertens Res. 2012;36(5):422-7.

31. Bozkurt B, Aguilar D, Deswal A, Dunbar SB, Francis GS, Horwich T, et al. Circulation. 2016;134(23):535-79.

32. Eckel RH, Jakicic JM, Ard JD, Jesus JM, Miller NH, Hubbard VS, et al. 2013 AHA/ACC guideline on lifestyle management to reduce cardiovascular risk: a report of the American College of Cardiology/American Heart Association Task Force on Practice Guidelines. J Am Coll Cardiol. 2014;63(25):2960-84.

33. Malachias MVB, Souza WKSB, Plavnik FL, Rodrigues CIS, Brandão AA, Neves MFT, et al. $7^{\text {a }}$ diretriz brasileira de hipertensão arterial. Rio de Janeiro: Sociedade Brasileira de Cardiologia; 2016.

34. Moncada S, Higgs EA. The discovery of nitric oxide and its role in vascular biology. Br J Pharmacol. 2006;147(S1):193-201.

35. Camargo MD, Stein R, Ribeiro JP, Schvartzman PR, Rizzatti MO, Schaan BD. Circuit weight training and cardiac morphology: a trial with magnetic resonance imaging. BMJ. 2008;42:141-5.

36. Silva NSL, Venturini GRO, Damasceno J, Farinatti PTV. Influência do treinamento resistido sobre a aptidão cardiorrespiratória em idosos. RBPFEX. 2016;10(60):486-96. 
37. Silva NL, Farinatti PTV. Influência do exercício contraresistência sobre o consumo de oxigênio e a frequência cardíaca de idosas. Motricidade. 2012;8(S2):659-66.

38. Verdijk LB, Loon L, Meijer K, Savelberg HHCM. Onerepetition maximum strength test represents a valid means to assess leg strength in vivo in humans. J Sport Sci. 2009;27(1):59-68.

39. Seo DI, Kim E, Fahs CA, Rossow L, Young K, Ferguson $\mathrm{SL}$, et al. Reliability of the one-repetition maximum test based on muscle group and gender. J Sports Sci Med. 2012;11(2):221-5.

40. American College of Sports Medicine, Chodzko-Zajko WJ, Proctor DN, Singh MAF, Minson CT, Nigg CR. American College of Sports Medicine position stand. Exercise and physical activity for older adults. Med Sci Sports Exerc. 2009;41(7):1510-30.

41. Radjab Y, Aboudrar S, Milouk FZ, Rkain H, Bakkali MEL, Dakka T, et al. Cardiovascular autonomic response to amlodipine in primary hypertension. ISRN Cardiol. 2012;2012.
42. Marzetti E, Calvani R, Tosato M, Cesari M, Bari M, Cherubini A, et al. Sarcopenia: an overview. Aging Clin Exp Res. 29(1):11-7.

43. Carvalho DA, Brito AF, Santos MAP, Nogueira FRS, Sá GGM, Neto JGO, et al. Prevalência da prática de exercícios físicos em idosos e sua relação com as dificuldades e a falta de aconselhamento profissional específico. R Bras Ci e Mov. 2017;25(1):29-40.

Received on $07 / 04 / 2018$

Recebido em 04/07/2018

Recibido em 04/07/2018

Approved on $11 / 26 / 2018$

Aprovado em 26/11/2018

Aprobado en 26/11/2018 